\title{
Is Faith in School Integration Bad Faith?
}

\author{
Michael S. Merry (University of Amsterdam)
}

\begin{abstract}
:
Many profess a belief in the importance of school integration. In this essay I argue that the evidence tells against the sincerity of this belief. ${ }^{1}$
\end{abstract}

Keywords:

bad faith; collective action; integration; segregation; virtue signaling

[It] is sentimental and romantic to assume that any education or any example will ever completely destroy the inclination of human nature to seek special advantages at the expense of, or in indifference to, the needs and interests of others.

\section{Reinhold Niebuhr}

Integration is an idea that refuses to die. In Europe, it is a perennial political obsession. Noteworthy in most discussions is how imprecise the notion of 'integration' is, let alone what its demands actually are. Conservatives and liberals alike employ the term to mean different things, though in political discourse it is safe to say that 'integration' is meant to signify a favorable orientation toward the dominant language or religion, educational success, labor market participation, endorsement of mainstream cultural values (e.g., equality between the sexes), and even attitudes and dispositions with respect to various institutional norms. Call this the civic variant of integration, one generally favored by political conservatives. Yet while there always will be some groups that are unduly inward-looking (e.g., Antwerp's Haredi), the evidence will show that worries about segregation of this sort are greatly exaggerated; indeed, the bigger threat is one of social exclusion (Gradstein \& Schiff, 2006; Merry, 2005; Spear et al., 2018).

But there is another sense in which the term is used. Here we find the belief that integration - for which the minimal prerequisite entails the spatial mixing of persons from different backgrounds - is an instrument for tackling inequality by bringing the less fortunate into contact with the more fortunate; opportunities for mixing, most especially in schools, will grant the former access to the cultural and social capital of the latter. The result will be greater upward mobility for the less fortunate by gaining access to the relevant social networks and resources that the privileged enjoy. In other words, integration is believed to be a catalyst-for-justice. The privileged, for their part, will ostensibly acquire greater tolerance and understanding by virtue of their exposure to how the other - less fortunate - half lives. Call this the paternalist variant of integration, one generally favored by political liberals. Given its (arguably) greater relevance to educational inequality, in this essay I devote most of my attention to this variant.

\section{Segregation}

Integration presupposes segregation. Spatial geographers and demographers tell us that segregation occurs whenever the proportions of two or more populations are not homogenous throughout a defined space. Plant and animals species are therefore usually - but not always - segregated; people, too, in societies throughout the world, are usually - but not always segregated according to language, cultural difference, religion, nationality, educational background, political allegiance and socioeconomic status.

To be sure, none of this means that demographic patterns are fixed. Empirical evidence (Hall \& Lee, 2010) shows, for example, that American suburbs are more diverse than ever; recent evidence from England and Wales, too, suggests that ethnic 'mixing' in neighborhoods and schools is increasing rather than decreasing (Harris \& Johnston, 2020). Rates of mixed marriages and crosscultural exchanges, too, have everywhere increased. Yet one can acknowledge these demographic developments and still plainly observe that spatial configurations of segregation are everywhere recognizable; school segregation indices in many countries, too, remain consistently high, whether between or within schools (Boterman et al., 2019; Francis \& Darrity, 2021; Jamil, 2017; Johnston et al., 2004; Krüger, 2014; Raman \& Tan, 2010; Treviño et al., 2018; Windle, 2021). Even where we find 'super-diversity' in neighborhoods and schools, we 
still observe patterns of segregation, i.e., keeping to one's own. In other words, segregation is the norm. Not necessarily hostility, just homophily.

This is not, however, how most sociologists ${ }^{2}-$ who tend to focus on its structural features - use the term; nor is it how the concept is understood among the general public. Indeed segregation is such an emotionally freighted ideanot unlike, say, patriarchy - that it simply goes without saying that we should want less of it. I do not dispute the historical and sociological evidence concerning pogroms, caste, Jim Crow, internment, apartheid or indeed any other kind of involuntary segregation whose design was - and in many countries, still is - to contain poor and usually stigmatized minority groups within specific geographic boundaries, thereby depriving them access to crucial resources and opportunities. Redlining in Rotterdam (Aalbers, 2007), the fenced containment and criminalization of Roma in Italy (Sigona, 2011), and 'ghetto planning' in Copenhagen ${ }^{3}$ each represent contemporary European examples.

Yet one can oppose compulsory segregation, as Bernard Boxill (1992, p. 184) has argued, and still not believe that integration is required in all life domains, or even most of the time. Given the value everyone ascribes to voluntary association, most of us can imagine a society in which persons can enjoy a variety of 'segregated experiences' in their private lives - being with others of one's choosing - so long as their loyalties are at least partially orientated toward the dominant culture, or so long as persons 'integrate themselves' in at least one major life domain, such as the labor market or military service. Segregation of this sort describes the copious ways in which persons usually prefer more homogenous company - in the sense of 'people like us' - even if, occasionally, they may enjoy an 'exotic' experience into a segregated enclave of another sort. Such is the allure of foreign travel.

Furthermore, one can oppose compulsory segregation and still be honest in one's assessment of the evidence concerning the terms of 'integration' as devised by majority groups and their respective governments, where time and again the aims - if not also the results - have approximated assimilation, and moreover where the burdens for achieving this so-called 'integration' are placed squarely on the backs of the most despised members of society, who - in many times and places - have been forcibly taken from their own communities into hostile environments where their language was forbidden, culture denied, and permanent subordination ensured. These are not realities banished to the dustbin of history, but rather ongoing, daily experiences of trauma and catastrophe for stigmatized minority groups numbering in the tens of millions around the world: the Cree, Rohingya, Sinti, Dalit, Uighur and so on. If those examples seem too far removed or extreme, there are plenty of more pedestrian ones across Europe and around the world (Diop, 2017; Judge, 2014; Li,
2020; Rafferty, 2020; Thijssen et al., 2019; Valfort, 2020).

\section{School Choice, Competition and Entitlement}

Disparity in the ability or opportunity to exercise the freedom of movement is one root of the problem of segregation, prompting some to push for restrictive school choice policies, or quotas. In some European countries, for instance, proposals annually circulate calling for school registration times that would give less privileged parents a chance to enroll in the school of their choice. Yet attempts to restrict parental choice for the privileged generally have had little effect. Not only do parents enjoy the constitutional right to choose an education they think is best, when push comes to shove nothing prevents determined parents from changing their address or navigating the system in other ways advantageous to their interests.

Competition in education has become so absurd in many European cities, for instance, that white, middleclass parents frantically place their newborn child on waiting lists for daycare centers, and the same occurs for the more 'desirable' primary schools - desirable, one does not need to be told, by virtue of how visibly white and middle-class the concentration of the school is. Years later, these same parents become panic-stricken at the thought that their child might not make the cut to the secondary school of their choice. Many resort to expensive test coaching to ensure higher test results with the aim of their child attending what they believe to be a 'good' school, which in a country like the Netherlands, everyone continues to unashamedly label a 'white' school. Similar jockeying for position occurs around the world, much of it via shadow education, i.e., private tutoring, and not only on the affluent Pacific Rim - encompassing Singapore, Taiwan, South Korea and Japan - but also in places as diverse as India, Egypt and Bangladesh (Bray \& Kwo, 2013).

Even if 'coerced integration' were politically or legally feasible, this kind of social engineering would do little to impede other structural factors from maintaining or increasing current levels of residential segregation. These include: transportation issues; limited seats available at the most desirable schools; selection criteria at the point of entry that set quotas on the types of pupils to be admitted; grouping and tracking mechanisms inside of schools that with the teacher's crucial assistance - sort and select pupils in ways often consistent with social class and ethnic/racial background; parental advocacy behaviors that ensure various types of preferential treatment; and peer group effects that may or may not be conducive to academic achievement. Nor can we ignore either the macro-level economic forces related to our global neoliberal regime that exacerbate inequalities and drive competition between schools, gentrification, ghettoization and rural impoverishment, among other segregating social 
phenomena.

Indeed, given existing levels of residential segregation on all continents - urban, suburban, and rural - it is also not practically possible (and almost always politically impossible) to redraw the lines that determine attendance in ways that would produce more 'integration'. And efforts to mix schools are not even feasible in many cities - from Brooklyn to Berlin to Brisbane - where the school population in many catchment areas either is overwhelmingly middle-class and 'white', or poor and 'non-white'. That is to say, integration - assuming, again, that it requires some degree of spatial mixing - is not even an option. Even when a neighborhood does happen to be mixed, local schools typically are not, as indeed is the case in my own hyper-diverse neighborhood in Amsterdam, where each and every morning the white parents ferry their own children away from the brown and Muslim kids who attend the school immediately behind my building. Similar segregation-producing avoidance occurs elsewhere around the globe.

All of this happens, of course, because parents avail themselves of their legal rights to select a school that conforms to their preferences for their own child, preferences that happen to correspond to racial and class homogeneity. Moreover, exercising their choice is in keeping with guarantees to be found in various international treaties and nearly all national constitutions. Yet in opting for a homogeneous school or classroom environment, parents need not overtly base their choices on an eagerness to avoid children unlike their own. If asked, they need only offer the socially acceptable (and often empirically verifiable) reason that their child will have better educational chances at the school they have chosen - very often a school recommended to them by a close friend or colleague.

And if school alternatives are not available or local options are restricted, nothing in principle can prevent determined parents from changing residence in order to access a school that satisfies theirs, or their child's, interests. The willingness to relocate on the promise of 'better schools' is not limited to parents of means: families in poverty will often take heroic measures to gain what they perceive to be opportunities for their child's advancement. This is, after all, a primary push factor for immigration.

\section{Fanciful Proposals}

Given the political inexpedience of re-organizing school districts and municipalities, or expecting parents to move, many believe that transporting pupils from segregated to more mixed settings might offer a solution. Whether through transfer programs, magnet schools, open access policies or other desegregation schemes, transportation does get some disadvantaged children redistributed to better schools. Integration advocates often point to the successes of these alternatives, even, as I have already noted, when the school environments into which visible and stigmatized minorities are placed are often inhospitable, and when intractable structural problems persist - structural problems that integration advocates, too, reluctantly concede.

But there are many other problems with 'transfers'. First, the traffic is almost exclusively in one direction: disadvantaged children (the few who are permitted to attend without raising the ire of the school administrators or parents concerned about a 'bad element' compromising their school quality) going to higher quality majority schools. Majority-minority schools, meanwhile, remain mostly segregated, but without some of their best pupils, who have taken advantage of the opportunity to attend higher status schools, often far from home and at great emotional cost to themselves. Not a few report feeling isolated, friendless, or in the better cases, simply being the token whose very presence serves as validation for how anti-racist everyone else in the school is. Yet once a school has reached a 'tipping point' of visible 'others, in no time at all most schools will begin sorting the 'disadvantaged' pupils for separate instruction - sometimes deploying inventive and counterintuitive strategies (Saatcioglu \& Skrtic, 2019) - or else risk losing their 'most involved' (read: resource-hoarding) parents (Calarco, 2018).

Where integration 'successes' actually occur - and, like solar eclipses, they do occur - they are legitimized by the dubious premise, related to the paternalist variant of integration, that what minority pupils need most is access to majority institutions and majority peers. And here we arrive at the second problem with 'transfers', viz., there is powerful evidence to impugn the salvific effects of integration for the stigmatized without a variety of other enabling conditions being present. The preponderance of evidence, which elsewhere I examine in meticulous detail, reveals time and again that those conditions are generally absent (Merry, 2013, 2020). In other words, school integration is not a proxy for justice.

The third problem with the transfer idea is the tendency to ignore the habit of segregating among privileged groups, and it is the privileged, after all, whose communities and schools - often deemed 'progressive' ${ }^{4}$ - are the most segregated of all. It therefore does not really matter which variant of integration one prefers, as the privileged remain the standard bearers. Hence as it concerns the civic variant, there is a strong implicit belief that one already embodies the virtues of 'good citizenship'; it is the 'others' whose ignorance about politics, but also whose cultural and religious attachments - not to mention one's linguistic and class 'deficits' - raise concern. Similarly, as it concerns the paternalist variant, the privileged embrace the comforting fiction that they already possess the requisite social and cultural capital that the 'others' purportedly need, and perhaps even envy. 


\section{Virtue Signaling}

These paternalist sentiments go hand-in-hand with unanimous support for school integration in liberal, welleducated circles. But here is the rub. Parents, administrators, and professors of racial/ethnic or class privilege are likely to accept 'integration' only if there is no perceived cost in terms of the academic opportunities for their own child and others like them. Indeed, it has long been my observation that most white liberals publicly campaign for school integration, while privately acting as if this same inclusion represented a threat to academic 'excellence', that is, as a threat to the quality of their own child's educational opportunity.

Thus even as one extols the virtues of 'integration', and even when one is apprised of the excellent reputation of the local school containing all the diversity one could ever want, the most unimpeachable leftist credentials in the world cannot persuade the average privileged parent to send their child to a school in which they believe their child's advantages will be even slightly compromised. A similar phenomenon was noted by George Orwell (1937/1962, p. 143) 90 years ago: "The middle-class I.L.P.'er and the bearded fruit-juice drinker are all for a classless society so long as they see the proletariat through the wrong end of the telescope."

To publicly endorse 'integration', then, becomes the beneficent gesture that hesitatingly welcomes pupils who many believe are underprepared and whose presence - in sufficient numbers - might well compromise school quality. And hence the few privileged parents who actually opt for 'integration' - though rarely without first consulting with the school principal to ensure that there either are accelerated tracks or gifted classes - can even be constructed as making a 'sacrifice' because privileged parents have the freedom to choose alternate settings that they feel would better satisfy their child's interests. Parents of means who enroll their child in so-called integrated schools, when they have other choices, even seem to feel that they have thus contributed something important to educational justice, and this belief may be socially reinforced by other parents who share the same conviction. After all, they, too, believe in the importance of having 'more diversity' in their child's education. Accordingly, the unceasing push for school integration might be understood as a way to feel better about oneself and one's choices.

This is not to say that privileged parents do not sincerely agonize over inequality or wish to do something about it. Nor does it mean that there are not very real priority conflicts one must confront, including trade-offs that favor partial treatment of one's own children over a political ideal. It does mean, however, that privileged parents - and here we must include a large number of scholars whose work focuses on educational inequality - appear to be particularly susceptible to virtue signaling where school integration is concerned. Whatever anguish one may have about segregation, it rarely suffices to influence the day-to-day decisions most make concerning residence, friendship or choice of school. Even if one's child attends a highly diverse school, beyond the earliest grades the internal tracking system of that school ensures minimal contact with others of different cultural and social class background, and, given the homophily effect on friendships, life outside of school is often just as predictably homogenous. The child's parents, too, devote their social lives to being with similar others, both in terms of social class background and political persuasion. And in the final analysis one's motives are neither here nor there, for homophily invariably produces these outcomes, even if historical injustice and economic inequality cement - and exacerbate - these patterns.

\section{Collective Action}

One response to the unyieldingness of school segregation - or segregation simpliciter - might be to say that there is a problem of 'collective action', whereby the failure to act on one's faith in integration stems not from a disingenuous belief, but rather from the fact that so few others are willing to make the relevant 'sacrifice'. Thus it is not the faith in integration that is the problem, but rather the unavoidable trade-off that comes with having to choose between that which serves one's short term interests (the education of one's own child) versus some greater good (an 'integrated society') that requires buy-in from more people with privilege.

But the collective action argument is problematic on multiple levels. First, unlike other common examples of collective action - such as using solar energy or public transportation - many educated parents believe 'integrated schooling' threatens their child's positional advantage, which renders dubious their belief in integration in the first place. Second, as we have seen, the liberal paternalist belief that 'integration' will level the playing field rests both on a deficit view of minority others and their schools, and a corresponding missionary-like attitude concerning what needs to happen to correct it. Moreover, though social desirability bias does not permit these things to be said aloud, the attitudes among the privileged concerning schools with 'too many minorities' insinuate racist beliefs about the children in these schools. Third, the dogged belief that low SES and stigmatized minority children will get a 'boost' from being allowed to attend schools with higher SES children is belied by the myriad facts concerning how school systems around the world are designed to discourage 'integration', let alone equitable treatment, from happening (Bell, 1980, 2005; Carter \& Merry, 2021; Darity, 2005; Shavit \& Blossfeld, 1993; Van de Werfhorst, 2019). ${ }^{5}$

In any case, there is abundant evidence to show that 
privileged parents game the system to their own child's advantage, no matter how 'integrated' the school is. ${ }^{6}$ Indeed, privileged parents can always rationalize their behaviour by conveniently invoking a trump: either a constitutional right to choose an education to one's satisfaction, or else a moral right of parental partiality, which permits - and arguably even requires - preferential treatment of one's own child. Importantly, non-privileged parents, too, possess these same prerogatives, including the right to reject an 'integrated' education premised on the soft bigotry of low expectations where one's child is simultaneously viewed as both hapless victim and fortunate beneficiary.

Doubtless many readers will be unhappy both with this analysis and with this outcome. But if one wishes to insist on integration no matter what, then it seems to me that one must be willing to repudiate more than historical injustice and structural inequality; one must also repudiate the value of voluntary association, both for oneself and others, including the right to live where one wishes and to socialize as one prefers. One must also reject constitutional rights whose purpose is to maximize liberal pluralism in educational provision both for one's own children and the children of others, which incidentally would entail rejecting not a small number of highly successful majorityminority schools, where de facto segregation has been turned to advantage (e.g., Chenoweth, 2007; Dobbie \& Fryer, 2011; Driessen et al., 2016; McGuire \& Tokunaga, 2020; Merry, 2013). This also would include a wide variety of tertiary institutions whose purpose is to better serve marginalized groups, e.g., Tribal colleges, Gallaudet University (for the deaf and hard-of-hearing) and historically Black colleges and universities (HCBUs), to name but a few.

All of this leaves the ardent supporter of school integration in a quandary, for it is doubtful whether even the most doctrinaire advocate will oppose these rights and liberties, let alone surrender one's own privileges. But then liberal faith-in-school-integration will strike many as hollow indeed. For when rationalization unfailingly supplies one with reasons not to act upon his or her purported beliefs, beliefs that are observably and consistently contradicted by one's behaviour, then the evidence points away from ordinary moral failure, and instead suggests self-deception. And if that is right, then faith-in-integration manifests all of the disingenuous qualities of bad faith.

\section{References}

Aalbers, M. B. (2007). What types of neighbourhoods are redlined? Journal of Housing and the Built Environment, 22(2), 177-198. https://doi.org/10.1007/s10901-007-9074-9

Bell, D. (1980). Brown v. Board of Education and the interest-convergence dilemma. Harvard Law Review, 93, 518-533. https://doi.org/10.2307/1340546

Bell, D. (2005). The unintended lessons in Brown v. Board of Education. NYLS Law Review, 49(4), 1053-1067.

Boterman, W., Musterd, S., Pacchi, C., \& Ranchi, C. (2019). School segregation in contemporary cities: Socio-spatial dynamics, institutional context and urban outcomes. Urban Studies, 56(15), 3055-3073.

https://doi.org/10.1177/0042098019868377

Boxill, B. (1992). Blacks and social justice. Rowman \& Littlefield.

Bray, M., \& Kwo, O. (2013). Behind the façade of fee-free education: Shadow education and its implications for social justice. Oxford Review of Education, 39(4), 480-497. https://doi.org/10.1080/03054985.2013.821852

Calarco, J. (2018). Negotiating opportunities: How the middle class secures advantages in school. Oxford University Press.

Carter, P., \& Merry, M. S. (2021). Wall to Wall: Examining the ecology of racial and educational inequality in research. White Paper. Spencer Foundation.

Chenoweth, K. (2007). It's being done: Academic success in unexpected schools. Harvard University Press.

Darity, W. (2005). Stratification economics: The role of intergroup inequality. Journal of Economics and Finance, 29(2), 144-153. https://doi.org/10.1007/BF02761550

Diette, T., Hamilton, D., Goldsmith, A., \& Darity, W. (2021). Does the Negro need separate schools? A retrospective analysis of the racial composition of schools and Black adult academic and economic success. Russell Sage Foundation. https://doi.org/10.7758/rsf.2021.7.1.10

Diop, A., Trung Le, K., Johnston, T., \& Ewers, M. (2017). Citizens' attitudes towards migrant workers in Qatar. Migration and Development, 6(1), 144-160. https://doi.org/10.1080/21632324.2015.1112558 
Dobbie, W., \& Fryer, R. (2011). Are high-quality schools enough to increase achievement among the poor? Evidence from the Harlem children's zone. American Economic Journal, 3(3), 158-187. https://doi.org/10.1257/app.3.3.158

Driessen, G., Agirdag, O., \& Merry, M. S. (2016). The gross and net effects of primary school denomination on pupil performance in the Netherlands. Educational Review, 68(4), 466-480. https://doi.org/10.1080/00131911.2015.1135880

DuBois, W. E. B. (1935). Does the Negro need separate schools? Journal of Negro Education, 4(3), 328-335. https://doi.org/10.2307/2291871

Dumont, H., Klinge, D., \& Maaz, K. (2019). The many (subtle) ways parents game the system: Mixed method evidence on the transition into secondary-school tracks in Germany. Sociology of Education, 92(2), 199-228. https://doi.org/10.1177/0038040719838223

Francis, D., \& Darity, W. (2021). Separate and unequal under one roof: How the legacy of racialized tracking perpetuates within-school segregation. Russell Sage Foundation. https://doi.org/10.7758/rsf.2021.7.1.11

Gradstein, M., \& Schiff, Y. M. (2006). The political economy of social exclusion, with implications for immigration policy. Journal of Population Economics, 19(2), 327-344. https://doi.org/10.1007/s00148-005-0016-0

Hall, M., \& Lee, B. (2010). How diverse are US suburbs? Urban Studies, 47(1), 3-28. https://doi.org/10.1177/0042098009346862

Harris, R., \& Johnston, R. (2020). Ethnic segregation between schools: Is it increasing or decreasing in England? University of Bristol Press. https://doi.org/10.1332/policypress/9781529204780.001.0001

Jamil, G. (2017). Accumulation by segregation: Muslim localities in Delhi. Oxford University Press. https://doi.org/10.1093/oso/9780199470655.001.0001

Johnston, R., Wilson, D., \& Burgess, S. (2004). School segregation in multiethnic England. Ethnicities, 4(2), $237-265$. https://doi.org/10.1177/1468796804042605

Judge, P. S. (Ed.). (2014). Mapping social exclusion in India: Caste, religion and borderlands. Cambridge University Press. https://doi.org/10.1017/CBO9781107296947

Korver-Glenn, E. (2021). Race Brokers: Housing markets and segregation in 21st century urban America. Oxford University Press. https://doi.org/10.1093/oso/9780190063863.003.0002

Krüger, N. (2014). Más allá del acceso: Segregación social e inequidad en el sistema educativo Argentino. Cuadernos de Economía, 33(63), 513-542. https://doi.org/10.15446/cuad.econ.v33n63.45344

Li, Y. (2020). Institutional discrimination and workplace racism: A double roadblock in the career paths of Chinese graduates in France. Journal of Chinese Overseas, 16(2), 267-301. https://doi.org/10.1163/17932548-12341426

McGuire, J., \& Tokunaga, T. (2020). Co-constructing belonging: 'Voluntary separation' in deaf and immigrant education in Japan. Japanese Studies, 40(3), 291-311. https://doi.org/10.1080/10371397.2020.1851177

Merry, M. S. (2005). Social exclusion of Muslim youth in Flemish-and French-speaking Belgian schools. Comparative Education Review, 49(1), 1-23. https://doi.org/10.1086/426158

Merry, M. S. (2013). Equality, citizenship and segregation: A defense of separation. Palgrave Macmillan. https://doi.org/10.1057/9781137033710

Merry, M. S. (2020). Educational justice: Liberal ideals, persistent inequality and the constructive uses of critique. Palgrave Macmillan. https://doi.org/10.1007/978-3-030-36023-8

Merry, M. S., \& Boterman, W. (2020). Educational inequality and state-sponsored elite schools: the case of the Dutch gymnasium. Comparative Education, 56(4), 522-546. https://doi.org/10.1080/03050068.2020.1771872

Orwell, G. (1962). The road to Wigan Pier. Penguin. (Original work published 1937)

Rafferty, A. (2020). Skill underutilization and under-skilling in Europe: The role of workplace discrimination. Work, Employment and Society, 34(2), 317-335. https://doi.org/10.1177/0950017019865692

Raman, S. R., \& Tan, Y. S. (2010). Ethnic segregation in Malaysia’s education system: Enrolment choices, preferential policies and desegregation. Paedagogica Historica, 46(1-2), 117-131. https://doi.org/10.1080/00309230903528496 
Saatcioglu, A., \& Skrtic, T. (2019). Categorization by organizations: Manipulation of disability categories in a racially desegregated school district. American Journal of Sociology, 125(1), 184-260. https://doi.org/10.1086/703957

Shavit, Y., \& Blossfeld, H. P. (1993). Persistent inequality: Changing educational attainment in thirteen countries. Social inequality series. Westview Press.

Sigona, N. (2011). The governance of Romani people in Italy: Discourse, policy and practice. Journal of Modern Italian Studies, 16(5), 590-606. https://doi.org/10.1080/1354571X.2011.622468

Spear, A., Defourny, R., \& Laville, J. L. (Eds.). (2018). Tackling social exclusion in Europe: The contribution of the social economy. Routledge. https://doi.org/10.4324/9781315204680

Thijssen, L., Yancee, B., Veit, S., \& Yemane, R. (2019). Discrimination against Turkish minorities in Germany and the Netherlands: Field experimental evidence on the effect of diagnostic information on labour market outcomes. Journal of Ethnic and Migration Studies, 47(6), 1222-1239. https://doi.org/10.1080/1369183X.2019.1622793

Treviño, E., Valenzuela, J. P., Villalobos, C., Béjares, C., Wyman, I., \& Allende, C. (2018). Agrupamiento por habilidad académica en el sistema escolar. Nueva evidencia para comprender las desigualdades del sistema educativo chileno. Revista Mexicana de investigación educative, 23(76), 45-71.

Valfort, A. M. (2020). Anti-Muslim discrimination in France: Evidence from a field experiment. World Development, 135, 115. https://doi.org/10.1016/j.worlddev.2020.105022

Van de Werfhorst, H. (2019). Early tracking and social inequality in educational attainment: Educational reforms in 21 European countries. American Journal of Education, 126(1), 65-99. https://doi.org/10.1086/705500

Windle, J. (2021). School segregation in Rio de Janeiro: Geographical, racial and historical dimensions of a centre-periphery dynamic. Comparative Education. [Online publication.] https://doi.org/10.1080/03050068.2021.1894868

\section{Recommended Citation}

Merry, M. S. (2021). Is faith in school integration bad faith? On Education. Journal for Research and Debate, 4(11). https://doi.org/10.17899/on_ed.2021.11.2

\section{About the Author}

Michael S. Merry is professor of philosophy in the department of Child Development and Education at the University of Amsterdam, The Netherlands.

\footnotetext{
1 A different version of this essay was published earlier this year under the title 'The Permanence of Segregation." Available at: https:/quillette.com/2021/04/16/the-permanence-of-segregation/

${ }^{2}$ The literature is vast, but for a recent example see Korver-Glenn (2021).

${ }^{3} \mathrm{https}$ //www.aljazeera.com/features/2020/1/15/denmarks-ghetto-plan-and-the-communities-it-targets

${ }^{4}$ In Europe these are often labeled 'free schools', e.g., Dalton, Jenaplan, Montessori and Steiner.

${ }^{5}$ In several European countries, including Germany, Austria, Switzerland and the Netherlands, selection begins at a very early age, channeling children into rigid higher and lower secondary school tracks; these are highly segmented by design and segregated by both class and ethnicity/race. For recent evidence from the Netherlands, see Merry \& Boterman (2020). In the United States, and using a stratification economics model, Diette et al. (2021) find that Blacks face more discrimination in racially-balanced schools than if they attend either predominately black or predominately white schools. Their study confirms DuBois' (1935) own hypothesis, which states that white peers, "as a result of their ability to influence the distribution of resources and opportunities within a school and their desire for preferred educational and economic outcomes, have a negative effect on educational attainment of black students" (2021, p. 170).

${ }^{6}$ The literature, again, is immense, but for recent evidence from Germany see: Dumont et al. (2019).
} 